\title{
DUFOUR GLANDS IN THE HYMENOPTERANS (APIDAE, FORMICIDAE, VESPIDAE): A REVIEW
}

\author{
ABDALLA, F. C. and CRUZ-LANDIM, C. da \\ Instituto de Biociências de Rio Claro, Departamento de Biologia, Unesp, Avenida 24A, 1515, Bela Vista, \\ CEP 13506-900, Rio Claro, SP, Brazil \\ Correspondence to: Fábio Camargo Abdalla, Departamento de Biologia, Unesp, Avenida 24A, 1515, Bela \\ Vista, CEP 13506-900, Rio Claro, SP, Brazil, e-mail: fabdalla@rc.unesp.br \\ Received June 10, 1999 - Accepted March 9, 2000 - Distributed February 28, 2001
}

(With 1 figure)

\begin{abstract}
Associated to the sting apparatus of the aculeate hymenopterans is found the poison gland, originated from the glands associated to the ovipositor of the non-aculeate hymenopterans and the less derived Dufour gland, homologue of the coletterial gland of other insects, and found in all hymenopteran females. The Dufour gland functions is mostly uncertain in hymenopterans but in ants it is involved with communication and defense and in non social bees with the nest building and protection. In wasps possibly with kin-recognition. Differences in morphology and chemical composition of the gland secretion were observed among species, in the same species, between the castes in the social species and among individual of the same caste playing different tasks or belonging to different nest. Its original function of egg-protective substance producing, or favoring the oviposition, appear to have been replaced or complemented in hymenopterans by the production of semiochemicals with function in communication.
\end{abstract}

Key words: Dufour gland, hymenopterans, morphology, pheromones, ultrastructure.

\section{RESUMO}

\section{Glândula de Dufour nos himenópteros (Apidae, Formicidae, Vespidae): uma revisão}

Anexas ao aparelho do ferrão dos himenópteros aculeados encontram-se as glândulas de veneno e as de Dufour. A glândula de veneno é originada das glândulas associadas ao ovopositor dos himenópteros ancestrais não aculeados, já a glândula de Dufour é menos derivada, homóloga das glândulas colateriais dos outros insetos, sendo encontrada em todas as fêmeas dos himenópteros. Nestes insetos sua função é, em grande parte, desconhecida, mas, em formigas, parece estar envolvida com a comunicação e a defesa e, nas abelhas não sociais, com a construção e a proteção do ninho. Nas vespas pode estar relacionada ao reconhecimento parental. Foram observadas diferenças morfológicas e na composição química da secreção da glândula de Dufour entre as espécies, bem como na mesma espécie, entre as castas dos himenópteros sociais e entre indivíduos da mesma casta desempenhando diferentes funções ou pertencentes a ninhos diferentes. Portanto, nos himenópteros, sua função original de produzir substâncias para proteger os ovos ou favorecer a ovoposição parece ter sido substituída ou complementada com a função de produzir semioquímicos com função na comunicação.

Palavras-chave: feromônios, glândula de Dufour, himenópteros, morfologia, ultra-estrutura.

\section{INTRODUCTION}

All insects present accessory glands associated to the female reproductive apparatus, which are denominated colleterial glands because their primary function is the production of substances to fasten the laid eggs to the substrate or to protect them during development. 
However, the pertinent literature register a variety of functions for these glands. In Periplaneta the eggs are laid in an ootheca consisting of tanned material produced by the reproductive accessory glands.

The frothy secretions which form the eggpods of grasshoppers and the gelatinous sheath of Chironomus eggs are also produced by the reproductive accessory glands. In Hydrophilus, the reproductive accessory glands produce silk which forms the cocoon in which the eggs are laid.

\section{THE STING GLANDS OF HYMENOPTERANS}

Female accessory glands often arise as an invagination of the genital chamber or the vagina, but some insects that developed long ovipositors and also special methods of posture, as the Symphyta and non-aculeate hymenopterans, also developed glands associated to the ovipositor, whose products, in some way, made possible the posture inside plants, animals or special nests.

In aculeate hymenopterans the ovipositor became the sting and the glands previously associated to it, changed to produce toxins used to immobilize preys given as food to the offspring and later, to defense. In Pompilidae and in others hymenopterans the poison serves to paralyze preys, but is also used in defense, to lubricate the ovipositor, or as via to chemical signals discharged through the sting.

Therefore, associated to the sting apparatus of aculeate hymenopterans there are two glands: 1. a gland corresponding to the colleterial gland, the Dufour gland, also known as alkaline gland, and 2. a gland corresponding to those associated to the ovipositor of the non-aculeate hymenopterans, the poison or acid gland (Carlet, 1884; Maschwitz \& Kloft, 1971; Hermann, 1969; Hermann \& Blum, 1967a, b, 1981).

The poison gland, as the name indicates, produces the poison, constituted mainly by proteinacious constituents in aqueous solution. In ants, as well as in bees and wasps, the gland ends in a poison sac that opens in the base of the sting, allowing the poison be injected immediately with the stinging.

The Dufour gland (Dufour, 1841) ends onto different locals among hymenopterans: in ants it opens in the base of the sting apparatus and in bees and wasps, in the vagina dorsal wa1l (Billen, 1987). However, in any case, both glands are totally independent in production and discharge of secretion (Maschwitz \& Kloft, 1971; Hermann \& Blum, 1981; Billen, 1982; Silveira, 1990).

Along evolution the original function of the coletterial glands (production of protective substance for the eggs) changed to pheromonal function in the Dufour gland. In Apis the Dufour gland secretion is used to mark the eggs laid by the queen (Katzav-Gozansky et al., 1997, 2000). This function of the gland can be considered derived from the original function.

\section{MORPHOLOGY OF THE DUFOUR'S GLAND IN HYMENOPTERANS}

The Dufour gland take different shapes in the hymenopterans, but is often described as a single tube or epithelial sac, involved by an incomplete muscular envelope, tracheoles and nerves (Bordas, 1894; Lello, 1968; Hermann \& Blum, 1967a, b; Landolt \& Akre, 1979; Downing \& Jeanne, 1983; Billen, 1986; Silveira, 1990; Abdalla, 1999; Abdalla \& Cruz-Landim, 1994; Abdalla et al., 1999a, b). The glandular epithelium is constituted by a single layer of cells, whose luminal surface is covered by a thick and undifferentiated cuticle (Crouch \& Smith, 1958; Barr-Nea et al., 1976; Billen, 1986; Billen \& Gotwald Jr., 1988; Billen et al., 1984; Barrows et al., 1986; Abdalla, 1999) secreted by the epithelial cells. Therefore the glandular cells, belong to class I glandular cells of Noirot \& Quennedey (1991) classification.

The cytoplasm of the glandular cells (Fig. 1) presents abundant mitochondria, smooth endoplasmic reticulum (SER) and some Golgi complexes (Billen, 1982, 1985, 1986, 1990; Billen \& Gotwald Jr., 1988; Barrows et al., 1986; Abdalla, 1999; Abdalla et al., 1999a, b), hence the subcellular structure is in accordance with the nature of the secretion, because the SER is involved with the synthesis and transportation of lipids (main compound in the Dufour gland secretion) and in bees, as well as, in ants, the glandular cells present few intracellular granules or secretion vesicles (Billen, 1982, 1985, 1986, 1990; Billen et al., 1984; Billen \& Gotwald Jr., 1988; Barrow et al., 1986; Abdalla, 1999; Abdalla et al., 1999a, b). 

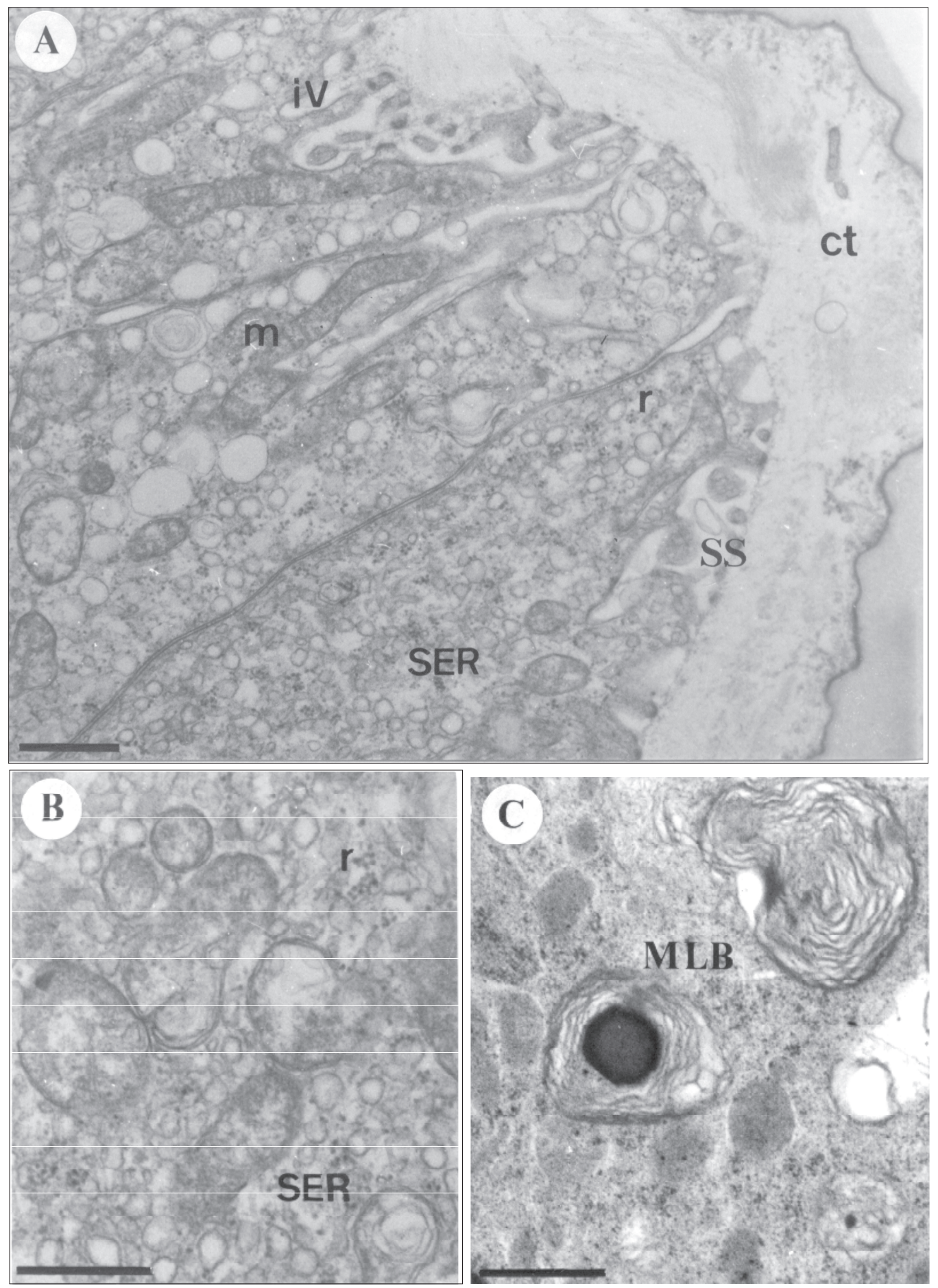

Fig. 1 - Ultrastructure of Dufour gland in Apis melifera (A, B) and Bombus terrestris (C). A) apical region showing the circular lining (ct), subcuticular space (SS), apical invagination (iv), mitochondria (m) and B) well developed smooth endoplasmic reticulum (SER), scar bar, $1 \mu \mathrm{m} ; \mathrm{r}=$ polyribosomes. $\mathrm{C}$ ) cytoplasmic detail showing multilamellar inclusions (MLB), scale bar $1 \mu \mathrm{m}$. 
There are few ultrastructural studies about the Dufour gland in bees and wasps. According Abdalla (1999) and Abdalla et al. (1999a, b) the cells of the Dufour's gland in Apis mellifera and in Bombus terrestris are morphologically similar to Noirot \& Quennedey (1991) class I glandular insect cell classification, in the sense that they are made by a single epithelium covered by cuticle. However, according Noirot \& Quennedey (1991) the class I cells sinthetyses the substances they eliminate throughtout the cuticle. In $B$. terrestris the morphological evidences show that at least part of the products of the secretion is uptaken directly from haemolymph, descharaterizing the epithelium as typically secretor. The way the uptaken substances reach the lumen is not totally clarified, but they may percolate through the intercellular space, does not passing through the epithelial cells, being storaged in the subcuticular space during a while; or may cross the cells being modified by them.

The chemical studies about the secretion of Bombus Dufour gland support this view. The same hydrocarbons on the body cuticle are found in the Dufour gland secretion (Tengö et al., 1991; Oldham et al., 1994). The composition of the gland secretion is different in individuals of the same species originating from different colonies. One explanation for this is the difference of the quality of stored food in the colonies (Hefetz et al., 1993). Probably stuffs absorbed by the midgut from the food digestion are uptaken from the hemolymph by the Dufour gland of Bombus and their quality differences reflected in the secretion composition. Besides as the Dufour gland products present intra and inter colonial variations according the substances collected and eating by the colony components, it is clear that the epithelial cells have a minor function, if any, in the synthesis of these products. If they were synthesized by the cells, as the synthetic via would be the same in a given species of similar individual phase, the products would not present such variation. Nevertheless, contrary to this view, in Nannotrigona testaceicornis queens, the only Meliponinae bee that have the compositon of the gland studied until know, there are none variation between specimens collected, as far as Brazil and Mexico (Cruz-Lopez et al., 2000).
In Apis the cells of the distal extremity of the queen gland are associated with oenocytes that are secretory cells and may contribute to the secretion composition. The epithelial cells that serves of via to oenocytes secretion elimination belong to Noirot \& Quennedey (1991) class II glandular cells. In this case the Dufour gland could be considerate a mixed gland, because in the same organ there are class I proximal cells and class II (associated to oenocytes) distal cells. In Bombus terrestris there are not oenocytes associated with the gland (Abdalla et al., 1999a).

In bees and mainly ants, it is common to observe multilamellar bodies in the cytoplasm of the glandular cells. According to Hefetz \& Orion (1982), these elements in Formicidae are a type of secretory vesicle containing hydrocarbons, being designated by Quennedey (1998) as myeloid secretion. The possibility that those structures reflect only reabsorption processes or cellular degeneration is also suggested (Gama \& Cruz-Landim, 1977).

Differences in the cellular organization of the Dufour glands can be found among subfamilies of ants. In Myrmecinae and Ponerinae the glandular epithelium does not present much variation, but in Dorylinae the luminal surface has a crenelated appearance and numerous basal invaginations, and in Ecitoninae the epithelium is very uniform with a basal layer labyrinth of plasmic membrane infoldings. Myrmecinae, Pseudomyrmecinae and Dolichoderinae each, show a different type of apical microvilli, whereas Formicidae exhibit a characteristic layer of mitochondria close to the cell luminal surface and a very thick basement membrane (Billen, 1986).

The size of the Dufour gland in hymenopterans vary in different castes and in individuals of different ages or doing different tasks. The major workers of slave-making ant species have the Dufour gland hypertrophied, while in other species are the minor workers that have the gland larger than the guardians. In the first case, the Dufour gland secretion is used in the usurpation process (Regnier \& Wilson, 1971) and in the later the minor, forager workers, used as trail pheromone (Law et al., 1965). In Formica sanguinea, a slavemaking species, the active forager workers have the Dufour gland larger than the young and old 
workers, because the first is more involved in nest attack activity (Ali et al., 1988b). Baioco \& Cunha (1990) observed in Monomorium pharaonis that the epithelium of the gland in virgin queens is more developed than in mated queens. In this species the Dufour gland produces sexual pheromones (Hölldobler \& Wüst, 1973; Buschinger, 1975).

According Lello (1968), the Dufour gland is larger in bees situated bellow in the philogenetic tree. In Colletidae, Halictidae and Andrenidae the gland is large (Lello, 1968), in Megachilidae there is a decreasing of its diameter, in Mellitidae there is a decreasing of its length and in Anthophoridae there is a decreasing in both dimensions, being the gland in Apidae small and even vestigial or absent in Meliponinae (Lello, 1968). According Kerr \& Lello (1962), in Meliponinae the virgin queens has the Dufour gland larger then the mated queens, being this situation inverse to that observed in Apis (Kerr \& Lello, 1962; Abdalla, 1999).

In social bees the Dufour gland development and functioning, appear to be under juvenile hormone (JH) control (Abdalla et al., 2001a). This hormone show higher haemolymph titles in queens and forager workers (Robinson \& Ratnieks, 1987), condition related to vitologenesis and etarious polyethism respectively. In Bombus and in Apis the Dufour gland diameter and its secretory activity in workers increase with the increasing of oocyte maturation in the ovary (Abdalla, 1999; Abdalla et al., 1999a, b), condition which is under HJ control. Thefore the apparent link between vitelogenesis and Dufour gland development may be mediated by the $\mathrm{JH}$.

In Polistes versicolor wasps the Dufour gland of the dominant female is more developed than in workers. The gland of the dominant female is deepest yellow and broad while in workers it is transparent and slender (Nascimento \& CruzLandim, 1997). In some Polistes species when the gland is inactive, its reservoir is opaque, white, and empty (Landolt \& Akre, 1979). In Polistes queens just emerging from winter diapause the gland is inactive, but with the eclosion of the first workers the gland of the queens become active, increasing in width and becoming filled with a yellow secretion, decreasing in activity again at the late summer (Landolt \& Akre, 1979). In P. fuscatus the gland is deeper yellow in the dominant females of co-foundress associates during the late pre-emergence stage. At other times this gland show poor indications of secretory activity, regardless of the rank of the individual. Glands in nonnesting wasps, maintained in pairs, secrete more actively than in those wasps keep solitary (Downing \& Jeanne, 1983).

\section{FUNCTIONS AND CHEMICAL SECRETION OF THE DUFOUR GLAND IN HYMENOPTERANS}

The main constituents of Dufour gland secretion are lipids with long chains of hydrocarbons and volatile oxygenated substances.

Because the opening of the Dufour gland in ants is in the sting, Billen (1987) suggests that in these hymenopterans the gland has functions associated to communication and defense, while in social bees, in which the gland opens in the vagina, may be involved mainly with reproduction. But, in some hymenopterans it may exercise multiple and non-specific functions according the place of secretion discharge, as suggested by Billen (1987).

Its products may be used for reproductive, behavioral, or other ecological proposals (Lello, 1968; Hefetz, 1987; Katzav-Gozansky et al., 1997, 2000; Abdalla \& Cruz-Landim, 2001b).

One of the functions frequently attributed to the Dufour gland in Formicidae is the production of trail pheromone (Wilson, 1962; Walsh et al. , 1965; Hangartner, 1969; Ritter et al. , 1977; Hefetz \& Orion, 1982), but the gland also produces sexual pheromone (Hölldobler \& Wüst, 1973) and queen control pheromones (Edwards \& Chambers, 1984). Its contents is also used by slave-making species in the raiding process (Ali et al., 1988b ), or as aggregation stimulus and recruitment pheromone (Cammaerts-Tricot, 1973; Morgan et al., 1977, Bestmann et al., 1995).

In ants the main hydrocarbons found in the Dufour gland are alkanes, hydrocarbons with saturated chains (without couples or triple linkages). The alkanes more frequently found are those constituted of a main chain with 11 carbons, designated n-Undecane (n-C11), succeded by n-Tridecane and n-Pentane. With smaller frequency, appear alkenes and alkines (hydrocarbons with unsaturated chains). 
According Morgan et al. (1977), hydrocarbons of the secretion have mainly a physical role, they represent solely a solvent for other volatile substances with pheromonal property. The hydorcarbons could also provide alterations in the sublimation point of the pheromonal substances present in secretion, prolonging the time of their action. Many authors think that the n-Undecane is a pheromone (Regnier \& Wilson, 1968, 1969; Ayre \& Blum, 1971; Bergströn \& Löfqvist, 1970, 1972a, b; Dumpert, 1972; Löfqvist, 1976) or a wetting agent to the formic acid produced by the poison gland (Löfqvist, 1977).

Surprisingly, most of the alkanes in pure state are solid at the room temperature. However, the Dufour gland secretion of the hymenopterans is constituted by a complex mixture of saturated and unsaturated hydrocarbons. The introduction of double linkages in the long hydrocarbon chains reduces the its melting point. Another strategy to maintain the secretion in liquid or viscous state is the introduction of double linkages with $\mathrm{Z}$ geometry in the middle of the main hydrocarbon chain. This linkage is much more efficient than those and is also frequently found in the Dufour gland secretion (Billen et al., 1986; Bagneres et al., 1991; Hefetz et al., 1996).

It was verified that the secretion of the Dufour gland varies not only with the age but with the functional tasks done by workers of social species. Among workers, is common that the youngest present secretion composed by simpler mixture of substances, generally constituted by one or few types of hydrocarbons, and that in older ones the secretion been incremented with more complex substances of pheromonal action (A1i et al., 1988b; Patrício, 1995). In slave-making ants Formica sanguinea, the quantity of farnesene (pheromone involved in the slave-making process) in the secretion of the Dufour gland changes during the life cycle of the workers. In young workers the main components of the secretion is the $n$ - Undecane that is gradually substituted by two isomeric forms of farnesene (Z-E-farnesene) in older workers that actuate in the slave-making process (Ali et al., 1988b).

Many functions have been described for this gland in bees. In non-social bees the gland produces hydrophobic lining and cementing substances for the nest (Lello, 1968; Hefetz et al., 1979, 1982;
Heletz, 1987; A1bans et al., 1980; Cane, 1981; Cane \& Brooks, 1983; Kronenberg \& Hefetz, 1984), sexual atractants (Smith et al., 1985), recognition or nestmarking (Bergströn \& Tengö, 1974; Shimron et al., 1985; Hefetz, 1987, 1990; Hefetz et al., 1993) or even trail pheromones (Vinson et al., 1978). Its secretion can serve a1so as larva1 food (Norden et al., 1980) and food source-marking pheromones (Franckie \& Vinson, 1977).

In social bees the role of the Dufour gland is not well known. In Apis (Snodgrass, 1956; CruzLandim, 1967; Abdalla, 1999), in Bombus (CruzLandim, 1967; Abdalla et al., 1999a, b) and in meliponines (Lello, 1962) the gland is larger in queens than in workers, besides in Apis its secretion has caste-specific constituents (Katzav-Gozansky et al., 1997). Due to this specificity some authors propose that the Dufour gland in Apis queens produces egg-marking pheromones to prevent its eggs of being eated by workers during the posture inspection (Ratnieks, 1993, 1995; Katzav-Gozansky et al., 1997).

In the Meliponinae, in spite of the sting atrophy, the Dufours gland is present in queens and, sometimes, also in workers (Lello, 1968), being, however, its function unknown.

In stingless ants, the Dufour gland is a 1 so present, an additional cue to function independent of the venom or sting gland.

Therefore, the Dufour gland, is found in all female Hymenopterans (Bordas, 1894; Lello, 1968; Landolt \& Akre, 1979; Cruz-Landim \& Saenz, 1972; Caetano et al., 1973; Billen, 1986).

In social ants as well as in bees the contents of the secretion present variations in its quantity and quality within species and castes (Hefetz, 1987; Ali et al., 1988a, b, c, 1989; Billen et al., 1983; Katzav-Gozansky et al., 1997, 2000). These variations are important for create specific, colonial or individual labels used to produce trail, nestmarking, nestmate recognition and egg- marking pheromones.

In some species of social wasps it has been hypothesized that the secretion of the Dufours gland may be applied to the body surface during the grooming and, becoming responsible by the kin recognition (Dani et al., 1996). In many social insects, as the bumble bees, is possible to found the same hydrocarbons on the exoskeleton and in the secretion of the Dufour gland (Tengö et al., 
1991). In Stenogastrinae wasps the gelatinous substance found involving the eggs and larvae of many species was interpreted as larva1 food secreted by the Dufour gland (Jacobson, 1988; Turillazzi \& Pardi, 1982).

According Turillazzi (1991) the secretion around the eggs has many other functions. It is used as a tool in oviposition, functions as a resting substrate for the small larvae, acts as a storage substrate for liquid or solid food for both larvae and adults and can serve as defense barriers against ants.

The production of egg-marking pheromones by queens to protect her eggs against be devoured by subordinates during times of intense reproductive competition among nestmate, also has been speculated for wasps (Akre et al., 1976; Greene et al., 1978; Landolt \& Akre, 1979; Downing \& Jeanne, 1983). The hole of a glue-like substance production to attach the eggs onto combs, has also been suggested (Wigglesworth, 1972).

In parasitic wasps the Dufour gland of queens produces pheromones to control the nest usurpation process (Landolt \& Akre, 1979). The gland of the parasitic queen may produce a stimulus, that makes her to appear as pheromonally superior to the host workers and therefore, more acceptable, than the host queen (Jeanne, 1977; Fletcher \& Blum, 1983). The secretion could also, mask or alter the odor of the host colony and thus confuse the host system impairing the recognition of nest from foreign queen, or it might alter worker behavior in such a way that makes the usurpation process easier (Schmidt et al., 1984)

Along the evolution of Dufour and venom glands, not only its morphology, as its function, have been modified and, in some cases, they took directions that withdraw them from the function associated to the reproduction. According Billen (1987) in ants the loss of the roles directly linked to the reproduction by Dufour gland was accompanied by the acquisition of holes related to communication and defense. This condition of the Dufour gland in ants has been favored by the absence of brood cells (and hence the superfluous function of producing cementing substances). The occurrence of free ambulatory brood, which is a genera1 but, unique aspect of ant social biology, supports this hypothesis, argue Billen (1987).
The same substances produced by the Dufour's gland can play different roles, as the macrocyclic lactones. In non-social bees that produce hydrophobic lining or cementing substances for the nest, these substances are derived from the macrocyclic lactones. When the species make subterranean nests the lactones are used to line the nest with a hydrophobic pellicule (Hefetz et al., 1979; Albans et al., 1980; Cane, 1981; Duffield et al., 1981), but when the nest is made above the soil (trees or branchs) the lactones are used as cimenting substances mixed with other materials (Cane, 1981; Cane \& Brooks, 1983). In Lasioglossum zephyrum, a primitively social species of bee, the lactones are used as sexual attractant pheromone (Smith et al., 1985).

A quite interesting multiple use of the Dufour gland secretion in bees occur with the triglycerides components. Some bees produce these substances in the Dufour gland and use it to line the nest or as larval food, eaten after the ending of the storaged supplies (Norden et al., 1980).

In Apis, the secretion of the queen Dufour gland contain wax-type esters absent from the worker secretion. These esters, according to Katzav-Gozansky et al. (1997) serve to label the queen eggs to prevent their elimination, during the inspection activity by the workers. Besides, the same authors verified that the secretion of the egg-laying workers from queen-less colonies contain the same esters, used by them to mimetize the queen eggs, preventing they of being eaten by other non laying workers. This fact suggests that the biosynthetic pathway of the esters are present in both caste, but, in some way, is inhibited in workers by the queen presence in the colony.

According Nascimento \& Cruz-Landim (1997) in the wasp P. versicolor the Dufour gland is deepest yellow in queens, while in workers it is transparent and thin. The co-founddress females, although having well developed ovaries, have the gland smaller than the other workers. In this species of wasps the gland may have a role in reproduction.

In wasps the wax-type esters are involved in the kin recognition (Dani et al., 1996). The production of these type of esters by the Dufour gland in bees is very frequent and also must have kin-recognition roles (Tengö et al., 1991; Oldham et al., 1994; Abdalla \& Cruz-Landim, 2001b). 


\section{CONCLUDING REMARKS}

The similarity of the Dufour gland components among the Hymenopterans seems to indicate that the biosynthetic pathways have been conserved in this gland during the evolutive process, once the gland synthesize the same class of chemicals even being morpho-functionally different. The same conservative process happens with the ultrastructural architecture of the glandular cells, corroborating this hypothesis.

During the evolution, the gland may have passed through an adaptation or modulation of the secreted chemical components, according the ecology of the species. According Abdalla (1999) and Abdalla et al. (1999a, b) part of the content of the secretion of the gland in A. mellifera and Bombus terrestris is uptaken directly from the haemolymph. This fact could explain the high conservation of the products found in glandular secretion, because the pathway of the lipid metabolization is similar in insects, suffering few modifications along evolution.

In Bombus the same hydrocarbons are found in the surface of the body and in the secretion of the Dufour gland. Morphological evidences suggest that the hydrocarbons could be uptake directly from haemolymph. In fact the composition of the gland secretion show inter-colonial variation and in bees and wasps the cuticular hydrocarbons on the surface body are used in the kin-recognition (the bee of each colony have particular composition of body surface hydrocarbons). The constancy of secretion composition verified in N. testaceicornis by CruzLopez et al. (2000) may indicate different hole in this bee species.

The chemical nature of the secretion, composed basically of lipids with saturated and unsaturated long chain hydrocarbons is consistent with the cellular organization of the gland, which has an extensive smooth endoplasmic reticulum, Golgi complexes and numerous mitochondria. The secretion, even so, does not seem to be totally produced by the epithelial cell and was not seen to accumulate in intracellular granules or vesicles but, instead, is released to the glandular lumen continually. According Abda1la (1999) in social bees the secretion activity of the queen gland can be higher in the reproductive phases and in workers can be stimulated by the juvenile hormone or queen absence (Abdalla et al., 2001b).

From the exposed, may be concluded that the Dufour gland is an example of the functional plasticity of the insects exocrine glands, as well as, of the possibility to use the same chemical mixtures to signalize different activities.

\section{REFERENCES}

ABDALLA, F. C., 1999, Estudo Comparativo da glândula de Dufour de Apis mellifera L. (Hymenoptera: Apidae) nas castas. Dissertação de Mestrado. Unesp, Rio Claro, SP, 180p.

ABDALLA, F. C. \& CRUZ-LANDIM, C. da, 1994, Anatomia e histologia das glândulas anexas ao ferrão de Pseudoaugochloropsis graminea (Hymenoptera: Halictidae). In: Anais do 210 Colóquio de Incentivo à Pesquisa, Instituto de Biociências, Letras e Ciências Exatas, Unesp, São José do Rio Preto, v. 1, p. 9.

ABDALLA, F. C., VELTHUIS, H. H. W., CRUZ-LANDIM, C. da \& DUChATEAU, M. J., 1999a, Changes in the morphology and ultrastructure of the Dufour's gland in during the life cycle of the bumble bee, Bombus terrestris L. queen (Hymenoptera: Bombini). Netherlands Journal of Zoology, 49: 251-262.

ABDALla, F. C., VELTHUIS, H. H. W., DUCHATEAU, M. J. \& CRUZ-LANDIM, C., 1999b, Secretory cycle of Dufour's Gland in workers of the bumble bee Bombus terrestris L. (Hymenoptera: Apidae, Bombini). Netherlands Journal of Zoology, 49: 139-156.

ABDALlA, F. C., GRACIOLI, L. F., SALLES, H. C., CRUZLANDIM, C. \& SILVA DE MORAES, R. L. M., 2001a, Effect of topic application of juvenile hormone $(\mathrm{JH})$ in honeybee worker larvae on the development of the Dufour's and Koschewnikow glands. Sociobiology, 37(1): 185-191.

ABDALLA, F. C. \& CRUZ-LANDIM, C., 2001b, Specificity of Dufour glandular secretion effect on the behaviour of forage worker of Apis mellifera (Hymenoptera: Apidae). Sociobiology, in press.

AKRE, R. D., GARnETT, W. B., MACDONALD, J. F., GREENE, A. \& LANDOLT, P., 1976, Behavior and colony development of Vespula pensylvanica and $v$ : atropilosa (Hymenoptera: Vespidae). J. Kansas Entomol. Soc., 49: 63-84.

ALBANS, K. R., APLIN, R. T., BREHCIST, J., MOORE, J. F. \& O'TOOLE, C., 1980, Dufour's gland and its role in secretion of nest cell lining in bees of the genus Colletes (Hymenoptera: Colletidae), J. Chem. Ecol., 6: 549-564.

ALI, M. F., ATTYGALlE, A. B., BILLEN, J. P. J. \& MORGAN, E. D., 1988a, Contents of Dufour glands in some fomicine ants: queens and workers of Camponotus aethiops and a re-examination of Lasiusfilliginosus, Entomol. Exp. Appl., 46: 109-115. 
ALI, M. F., ATTYGAlle, A. B., BILLEN, J. P. J., JACKSON, B. D. \& MORGAN, E. D., 1988b, Change of Dufour gland contents with age of workers of Formica sanguinea (Hymenoptera: Formicidae), Physiol. Entomol., 13: 249:255.

ALI, M. F., BILLEN, J. P. J., JACKSON, B. D. \& MORGAN, E. D., 1988c, Secretion of the Dufour of two african desert ants, Camponotus aegyptiacus and Cataglyphis savignyi (Hymenoptera: Formicidae), Biochemical Systematics and Ecology, 16(718): 647-654.

ALI, M. F., BILLEN, J. P. J., JACKSON, B. D. \& MORGAN, E. D., 1989, The Dufour gland contents of three species of Euro-african Messor ants and a comparison with those of North American Pogonomyrmex (Hymenoptera: Formicidae), Biochemical Systematics and Ecology, 17(6): 469-477.

AYRE, G. L. \& BLUM, M. S., 1971, Attraction and alarm of ants (Camponotus ssp.-Hymenoptera: Formicidae) by pheromones. Physiol. Zool., 44: 77-83.

BAGNeres, A. G., BILLEN, J. P. J. \& MORGAN, E. D., 1991, Volatile secretion of Dufour gland of workers of an army ant, Dorylus (Anomma) molestus. J. Chem. Ecol., 7(8): 1633-1639.

BAIOCO, L. M. \& CUNHA, M. A. S. da., 1990, Histologia das glândulas exócrinas em rainhas de Monomorium pharaonis (Linnaeus, 1758) (Hymenoptera: Formicidae). Rio Claro, SP, 43p. Monografia apresentada ao Instituto de Biociências para obtenção do grau de Bacharel em Ciências Biológicas, Unesp, Rio Claro.

BARR-NEA, L., ROSEMBERG, P. \& ISHAY, J., 1976, The venom apparatus of Vespa orientalis: morphology and cytology. Toxicon, 14: 65-68.

BARROWS, E. M., CHAPMAN, G. B., ZENEL, J. E. \& BLAKE, A. S., 1986, Ultrastructure of Dufour's glands in active and inactive hom-faced bees, Osmia corinfrons (Hymenoptera: Megachilidae). J. Kansas Entomol., 59(3): 480493.

BERGSTRÖN, G. \& LÖFQVIST, J., 1970, Chemical basis for odour communication in four species of lasius ants, $J$. Insect Physiol., 16: 2353-2375.

BERGSTRÖN, G. \& LÖFQVIST, J., 1972a, Camponotus ligniperda Latr. a model for the composite volatile secretions of Dufour's gland in Formicidae ants, pp. 195-123. In: A. S. Tahori (ed.), Chemical Releasers in Insects, $3^{\text {th }}$ vol. Gordon and Breach, New York, Proc. $2^{\text {nd }}$ IUPAC Int. Congr. Pest. Chem., Tel Aviv 1971.

BERGSTRÖN, G. \& LÖFQVIST, J., 1972b, Similarities between the Dufour gland secretion of the ants Componotus ligniperda (Latr.) and Componotus herculeanus (L.). Entomol. Scand., 3: 225-238.

BERGSTRÖN, G. \& TENGÖ, J., 1974, Studies on natural odoriferous compounds. IX. Farnesyl and geranyl esters as main volatile constituents of the secretion from Dufour' s gland of 6 species of Andrena (Hymenoptera, Apidae). Chemica Scripta, 5: 28-38.
BESTMANN, H. J., JANSSEN, E., KERU, F. \& LIEPOLD, B., 1995, All-trans geranylgeranyl acetate and geranylgeraniol, recruitment pheromone components in the Dufour gland of the Ponerinae ant Ectotomma ruidum. Naturwissenschaften, 82: 334-336.

BILLEN, J. P. J., 1982, The Dufour gland closing apparatus in Formica sanguinea Latreille (Hymenoptera, Formicidae). Zoomorphology, 99: 235-244.

BILLEN, J. P. J., 1985, Comparative ultrastructure of the poison and Dufour glands in old and new world army ants (Hymenoptera, Formicidae), Actes Coll. Insectes Soc., 2: 17-26.

BILLEN, J. P. J., 1986, Comparative morphology and ultrastructure of the Dufour's gland in ants (Hymenoptera: Formicidae). Entomol. Gener., 11(314): 165-181.

BILLEN, J. P. J., 1987, New structural aspects of the Dufour's gland and venom gland in social insects. Naturwissenschaften, 74: 340-341.

BILLEN, J. P. J., 1990, Morphology and Ultrastructure of the Dufour's and venom gland in the ant Myrmecia gulosa (Fabr.) (Hymenoptera: Formicidae), Aust. J. Zool., 38: 305-315.

BILLEN, J. P. J., BOVEN VAN, J. K. A., EVERSHED, R. P. \& MORGAN, E. D., 1983, The chemical composition of the Dufour gland contents of workers of the ant Formica cunicularia a test for recognition of the species. In: Annls. Soc. R. Zool. Belg., 113(1): 283-289.

BILLEN, J. P. J., EVERSHED, R. P., ATTYGALLE, A. B., MORGAN, E. D. \& OLLETT, D. G., 1986, Contents of Dufours glands of workers of three species of Tetramorium (Hymenoptera: Formicidae). J. Chem. Ecol., 12(3): 669-685.

BILLEN, J. P. J., EVERSHED, R. P. \& MORGAN, E. D., 1984, Morphological comparison of Dufour glands in workers of Acromyrmex octospinosus and Myrmica rubra. Entomol. Exp. Appl., 35: 205-213.

BILLEN, J. P. J. \& GOTWALD JR., W. H., 1988, The crenellate lining of the Dufour gland in the genus Aenictus: a new character for interpreting the phylogeny of old world anny ants (Hymenoptera, Formicidae, Dorylinae). Zoologica Scripta, 7(3): 293:295.

BORDAS, M. L., 1894, Appareil glandulaire des hyménopteres. Tese presenté á La Faculté des Sciences de Paris pour obtenir le grade de docteur en Sciences Naturelles, Librarie de l' Académie de Médecine, Paris, série A, 362 p.

BUSCHINGER, A., 1975, Sexual pheromones in ants. In: Symposium pheromones and defensive secretions in social insects, Dijon. Proceedings, pp. 225-233.

CAETANO, F. H., LELLO, E. \& GAETTI, E. O., 1973, Estudo comparativo das glândulas anexas ao ferrão de formigas cortadeiras do gênero Atta. In: Resumos da XXV Reunião Anual da SBPC. 
CAMMAERTS-TRICOT, M. C., 1973, Phéromones agrégeant les ouvrières de Myrmica rubra. J. Insect Physiol., 19: 1299-1315.

CANE, J. H., 1981, Dufour's gland secretion in the cellinings of bees (Hymenoptera: Apoidea). J. Chem. Ecol., 7(2): 403-410.

CANE, J. H. \& BROOKS, R. W., 1983, Dufour's gland lipid chemistry of three species of Centris bees (Hymenoptera, Apoidea, Anthophoridae). Comp. Biochem. Physiol., 76B: 895-897.

CARLET, G., 1884, Sur le venin des Hyménopteres et ses organes sécréteurs, C. R. Acad Sci., Paris, 98: 1550-1551.

CROUCH, G. G. \& SMITH, C. M., 1958, Polistes exclamans vierek: The anatomy of the stinging apparatus. Texas $\mathrm{J}$. Sci., 10: 38-59.

CRUZ-LANDIM, C. da., 1967, Ultra-estrutura das glândulas básicas de Bombus e Apis. Cienc. Cult., 19: 266-267.

CRUZ-LANDIM, C. da \& SAENZ, M. H. P, 1972, Estudo comparativo de algumas glândulas nos Vespoidea .(Hymenoptera). Papéis avulsos de Zoologia, 26(24): 251263.

CRUZ-LOPEZ, L., PATRICIO, E. F. L. R. A. \& MORGAN, E. D., 2000, Secretion of stingless bees: the Dufour gland of Nannotrigona testaceicornis. J. Chem. Ecol., in press.

DANI, F. R., FRATINI, S. \& TURILLAZZI, S., 1996, Behavioural evidence for the involvement of Dufour's gland secretion in nestmate recognition in the social wasp Polistes dominulus (Hymenoptera: Vespidae). Behav. Ecol. Sociobiol., v. 38, pp. 311-319.

DOWNING, H. A. \& JEANNE, R. L., 1983, Correlation of season and dominance status with activity of exocrine glands in Polistes fuscatus (Hymenoptera: Vespidae). $J$. Kansas Entomol. Soc., (56): 387-397.

DUFFIELD, R. M., FERNANDES, A., LAMB, C., WHEELER, J. W. \& EICKWORT, G. C., 1981, Macrocyclic lactones and isopentenyl esters in the Dufour's gland secretion of halictine bees (Hymenoptera: Halictinae). J. Chem. Ecol, 7: 319-331.

DUFOUR, L., 1841, Reserches anatomiques et physiologiques sur les orthopteres, les hyménopteres et les névropteres, Paris, 647 p. Mémoires Présenteés par Divers Savants a 1'Académie Royale des Sciences de 1' Institut de France.

DUMPERT, K., 1972, Alarmstoffr ezeptoren ouf der Antenne von Lasius fuliginosus (Latr.) (Hymenoptera: Formicidae). Z. Vergl. Physiol., 76: 403-425.

EDWARDS, J. P. \& CHAMBERS, J., 1984, Identification and source of a queen-specific chemical in the pharaoh's ant, Monomorium pharaonis (L.), J. Chem. Ecol., 10: 17311747.

FLETCHER, D. J. C. \& BLUM, M. S., 1983, Regulation of queen number by workers in colonies of social insects. Science, 219: 312-314.

FRANCKIE, G. W. \& VINSON, S. B., 1977, Scent marking of passion flowers in Texas by female Xylocopa virginica texana (Hymenoptera: Anthophoridae). J. Kansas Entomol., 50: 613-625.
GAMA, V. \& CRUZ-LANDIM, C. da, 1977, Ultra-estrutura das glândulas anexas ao ferrão de Camponotus rufipes (Fabricius) (Hymenoptera:Formicidae). Bolm. Zool., 2: 135-157.

GREENE, A., AKRE, R. D. \& LANDOLT, P. J., 1978, Behavior of the yellowjacket social parasite, Dolichovespula arctica (Rohwer) (Hymenoptera: Vespidae). Melanderia, 29: $1-28$.

HANGARTNER, W., 1969, Trail laying in the subterranean ant, Acanthomyops interjectus, J. Insect Physiol., 15(1): $1-4$

HEFETZ, A., 1990, Individual badges and specific messages in multicomponent pheromones of bees (Hymenoptera: Apidae). Entomol. Gener., 15: 103-113.

HEFETZ, A., 1987, The role of Dufour's gland secretions in bees. Physiol. Entomol., 12: 243-253.

HEFETZ, A., EICKWORT, G. C., BLUM, M. S., CANE, J. \& BOHART, G. E., 1982, A comparative study of the exocrine products of cleptoparasitic bees (Holcopasities) and their hosts (Calliopsis) (Hymenoptera: Anthophoridae, Andrenidae), J. Chem. Ecol., 8: 1389-1397.

HEFETZ, A., FALES, H. M. \& BATRA, S. W. T., 1979, Natural polyesters: Dufour's gland macrocyclic lactones in the brood cell laminesters in Colletes bees. Science, 204: 415-417.

HEFETZ, A. \& ORION, T., 1982, Pheromones of ants ofIsrael: I. The alarm-defense system of some larger Formicinae, Isr. J. Entomol., 16: 87-97.

HEFETZ, A., TAGHIZADEH, T. \& FRANCKE, W., 1996, The exocrinology ofthe queen bumble bee Bombus terrestris (Hymenoptera: Apidae, Bombini). Z. Naturforsch, 51C: 406-422.

HEFETZ, A, TENGÖ, J., LÜBKE, G. \& FRANCKE, W., 1993, Inter-colonial and intra-colonial variation in Dufour's gland secretion in the bumble bee species Bombus hypnorum (Hymenoptera: Apidae), pp. 469-480. In: K. Weise, F. G. Gribakin \& G. Renninger (eds.), Sensory Systems of Arthropods. Birkhäuse Verlag, Basel.

HERMANN, H. R., 1969, The hymenoptera poison apparatus: evolutionary trends in three closely related subfamilies of ants (Hymenoptera: Formicidae). Georgia Entomol. Soc., 4: 123-141.

HERMANN, H. R. \& BLUM, M. S., 1967a, The morphology and histology of the hymenopterous poison apparatus, II: Pogonomyrmex badius (Formicidae). In: Annals of the Entomological Society of America, 60(3): 661-668.

HERMANN, H. R. \& Blum, M. S., 1967b, The morphology and histology ofthe hymenopterous poison apparatus, III: Eciton hamatum (Formicidae). In: Annals of the Entomological Society of America, 60(6): 1282-1291.

HERMANN, H. R. \& BLUM, M. S., 1981, Defensive mechanisms in social Hymenoptera, pp. 77-197. In: H. R. Hermann (ed.), Social Insects. $2^{\text {nd }}$ vol, 491p. Academic Press Inc., New York. 
HÖLLDOBLER, B. \& WÜST, M., 1973, Ein Sexual pheromon bei der Pharaoameisen Monomorium pharaonis (L.). Z. Tierphysiol., 32: 1-9.

JACOBSON, E., 1988, Aateekeningen over Stenogastrinae (Hymenoptera, Vespidae). (1935). Entomol. Meded. Ned.-Indie, 1: 15-19 (English translation) In: C. K. Starr. 1988. Sphecos (16): 17-19.

JEANNE, R. L., 1977, Behavior of the obligate social parasite Vestula arctica (Hymenoptera: Vespidae), J. Kansas Entomol. Soc., 50: 541-557.

KATZAV-GOZANSKY, T., SOROKER, V., HEFETZ, A., COJOCARU, M., ERDMANN, D. H. \& FRANCKE, W., 1997, Plasticity of caste-specific Dufour's gland secretion in the honey bee (Apis mellifera L.). Naturwissenscha. ften, 84: 238-241.

KATZAV-GOZANSKY, T., SOROKER, V. \& HEFETZ, A., 2000 , Plasticity in caste related exocrine secretion biosynthesis in the honey bee (Apis mellifera). J. Ins. Physiol., 46: 993-998.

KERR, E. W. \& LELLO, E., 1962, Sting glands in stingless bees. A vestigial character (Hymenoptera: Apidae). J. New York Entomol. Soc., 70: 190-214.

KRONENBERG, S. \& HEFETZ, A., 1984, Comparative analysis of Dufour's gland secretions of two carpenter bees (Xylocopinae: Anthophoridae) with different nesting habits. Comp. Biochem. Physiol., 79B(3): 421-425.

LANDOLT, P. \& AKRE, D., 1979, Occurence and location of exocrine glands in some social Vespidae (Hyrnenoptera). In: Annals. Entomol. Soc. Amer., 72: 141-148.

LAW, J. H., WILSON, E. O. \& McCLOSKEY, 1965, Biochemical polymorphism in ants. Science, 149: 544-546.

LELLO, E., 1968, Glândulas anexas ao aparelho de ferrão das abelhas (Hymenoptera: Apoidea). Tese de Doutorado, Fac. Fil. Ciências e Letras, Rio Claro, SP, 129p.

LÖFQVIST, J., 1976, Formic acid and saturated hydrocarbons as alarm pheromones for the ant Formica rubra. J. Insect Physiol., 22: 1331-1346.

LÖFQVIST, J, 1977, Toxic properties of the chemical defence systems in Formica rufa L. and Formica sanguinea Latr.: two competitive species, Oikoz, 28: 137-151.

MASCHWITZ, U. \& KLOFT, W., 1971, Morphology and function of the venom apparatus of insects-bees, wasps, ants and caterpilars, pp. 1-59. In: W. Bucherl \& E. E. Buckley (eds.), Venomous AnimaIs and their venoms, $3^{\text {th }}$ vol., New York, Academic Press.

MORGAN, E. D., TYLER, R. C. \& CAMMAERTS, M. C., 1977, Identification of the components of Dufour's gland secretion of the ant Myrmica rubra and responses to them., J. Insect Physiol., 23: 511-515.

NASCIMENTO, F. S. do \& CRUZ-LANDIM, C. da., 1997, Correlação da hierarquia social de dominância com o desenvolvimento das glândulas associadas ao aparelho de ferrão de Polistes versicolor (Olivier, 1791) (Hymenoptera: Vespidae). Rev. Brasil. Biol., 57(4): 709-718.
NOIROT, C. \& QUENNEDEY, A., 1991, Glands, gland cells, glandular units: some comments on terminology and classification. In: Anna1s Soc. Ent. Fr. (NS), 27: 123-128.

NORDEN, B. B., BATRA, S. W. T., FALES, H. M., HEFETZ, A. \& SHAW, J. C., 1980, Anthophora bees; unusua1 glycerides from materna1 Dufour's gland serve as larval food and cell lining. Science, 207: 1095-1097.

OLDHAM, N., BILLEN, J. \& MORGAN, E. D., 1994, On the similarity of the Dufour's gland secretion and the cuticular hydrocarbons of some bumble bess, Physiol. Entomol., 19: 115-123.

PATRÍCIO, E. F. L. R. A., 1995, Glândulas de Dufour em abelhas sem ferrão. Tese de doutorado, Instituto de Biociências, Pós-graduação em Zoologia, Unesp, Rio Claro, SP, 166p.

QUENNEDEY, A., 1998, Insect epiderma1 gland cells: ultrastructure and morphogenesis, pp. 177-207. In: Microscopic Anatomy of Invertebrates, vol. 11 A Insecta, Wiley-Liss. Inc.

RATNIEKS, F. L. W., 1993, Egg-laying, egg-removal, and ovary development by workers inqueenright honey bee colonies. Behav. Ecol. Sociobiol., 32: 191-198.

RATNIEKS, F. L. W., 1995, Evidence for a queen-produced egg-marking pheromone and its use in worker policing in the honey bee. J. Apicul. Res., 34: 31-37.

REGNIER, F. E. \& WILSON, E. O., 1968, The alarm-defense system of the ant Acanthomyops claviger, J. Insect Physiol., 14(7): 955-970.

REGNIER, F. E. \& WILSON, E. O., 1969, The alarm-defense system of the ant Lasius alienus. J. Insect Physiol., 15(5): 893-898.

REGNIER, F. E. \& WILSON, E. O., 1971, Chemical communication and "propaganda" in slave-maker ants., Science, 172: 267-269.

RITTER, F. J., BRÜGGEMANN-ROTGANS, I. E. M., VERWIEL, P. E. J., PERSOONS, C. J. \& TA1MAN, E., 1977, Trail pheromones of the Pharaoh's ant, Monomorium pharaonis: isolation and identification of Faranal, a terpenoid related to juvenile hormone II. Tetrahedron Lett., London, 30: 2617-2618.

ROBINSON, G. E. \& RATNIEKS, F. L. W., 1987, Induction of premature honey bee (Hymenoptera: Apidae) flight by juvenile hormone analogs administered orally or topically. J. Econ. Ent., 80: 784-787.

SCHMIDT, J. O., REED, H. C. \& AKRE, R. D., 1984, Veno$\mathrm{ms}$ of a parasitic and two nonparasitic species ofyellowjackets (Hymenoptera: Vespidae), J. Kansas Entomol. Soc., 57: 316-322.

SILVEIRA, O. T., 1990, Morfologia comparada das glândulas associadas ao aparelho de ferrão de al gumas espécies de vespas (Hymenoptera: Vespidae). Dissertação de Mestrado, Instituto de Biociências, Pós-graduação em Zoologia, Unesp, Rio Claro, SP, 98p. 
SHIMRON, O, HEFETZ, A. \& TENGÖ, J., 1985, Structura1 and comunicative functions of Dufour's gland secretion in Eucera palestine (Hymenoptera: Anthophoridae). Insect Biochem., 15: 635-638.

SMITH, B. H., CARLSON, R. G. \& FRAZIER, J., 1985 Identification and bioassay of macrocyclic lactone sex pheromone of the ha1ictine bee Lasioglossum zephyrum. J. Chem. Ecol., 11: 1147-1456

SNODGRASS, R. E., 1956, Anatomy of the honey bee Comstock Publ. Ass. Conell Univ. Press, 344p, Ithaca, NY.

TENGÖ, J., HEFETZ, A., BERTSCH, A., SCHMITT, U., LÜBKES, G. \& FRANCKE, W., 1991, Species specificity and complexity of Dufour's gland secretion of bumble bees. Comp. Biochem. Physiol., 99b: 641-646.

TURILLAZZI, S., 1991, The Stenogastrinae, pp 74-98. In: K. G. Ross \& R. W. Matheus (eds.), The social biology of wasps. 1 ed. Comstock Publishing Associates Press, London, 678p.
TURILLAZZI, S. \& PARDI, L., 1982, Ant guards on nests of Parischnogaster nigricans serrei (Boysson) (Stenogastrinae). Monit. Zool. Ital. (N.S.), 15: 1-17.

VINSON, S. B., FRANKIE, G. W., BLUM, M. S. \& WHEELER, J. W., 1978, Isolation, identification and function of the Dufour's gland secretion of Xylocopa virginica texana (Hymenoptera: Anthophoridae), $J$. Chem. Ecol., 4: 315-323.

WALSH, C. T., LAW, J. H. \& WILSON, E. O., 1965, Purification ofthe fire ant trail substance. Nature, London, 207: $320-321$

WILSON, E. O., 1962, Chemical communication among workers of the fire ant Solenopsis saevissima (Fr. Smith). 1. The organization of mass-foraging. 2. An information analysis of the odour trail. 3. The experimental induction of social responses. Animal Behaviour, 10(1-2): 134164.

WIGGLESWORTH, V. B., 1972, The principles of insects physiology. Wiley, New York. 